\title{
Biochemical patterns in ovine cheese: Influence of probiotic strains
}

\author{
M. Albenzio, ${ }^{* 1}$ A. Santillo, ${ }^{*}$ M. Caroprese,${ }^{*}$ R. Marino, ${ }^{*}$ A. Trani, $\dagger$ and M. Faccia \\ *Department of Production Sciences, Engineering, and Economics for Agricultural Systems (PrIME), University of Foggia, Foggia, 71100 Italy \\ †Dipartimento di Progettazione e Gestione dei Sistemi Agro-Zootecnici e Forestali, University of Bari, Bari, 70124 Italy
}

\begin{abstract}
This study was undertaken to evaluate the effect of lamb rennet paste containing probiotic strains on proteolysis, lipolysis, and glycolysis of ovine cheese manufactured with starter cultures. Cheeses included control cheese made with rennet paste, cheese made with rennet paste containing Lactobacillus acidophilus culture (LA-5), and cheese made with rennet paste containing a mix of Bifidobacterium lactis (BB-12) and Bifidobacterium longum (BB-46). Cheeses were sampled at 1, 7, 15 , and $30 \mathrm{~d}$ of ripening. Starter cultures coupled with probiotics strains contained in rennet paste affected the acidification and coagulation phases leading to the lowest $\mathrm{pH}$ in curd and cheese containing probiotics during ripening. As consequence, maturing cheese profiles were different among cheese treatments. Cheeses produced using rennet paste containing probiotics displayed higher percentages of $\alpha_{\mathrm{S} 1}$-I-casein fraction than traditional cheese up to $15 \mathrm{~d}$ of ripening. This result could be an outcome of the greater hydrolysis of $\alpha$-casein fraction, attributed to higher activity of the residual chymosin. Further evidence for this trend is available in chromatograms of water-soluble nitrogen fractions, which indicated a more complex profile in cheeses made using lamb paste containing probiotics versus traditional cheese. Differences can be observed for the peaks eluted in the highly hydrophobic zone being higher in cheeses containing probiotics. The proteolytic activity of probiotic bacteria led to increased accumulation of free amino acids. Their concentrations in cheese made with rennet paste containing $L b$. acidophilus culture and cheese made with rennet paste containing a mix of $B$. lactis and B. longum were approximately 2.5 and 3.0 times higher, respectively, than in traditional cheese. Principal component analysis showed a more intense lipolysis in terms of both free fatty acids and conjugated linoleic acid content in probiotic cheeses; in particular, the lipolytic pattern of cheeses containing Lb. acidophilus is distinguished from the other cheeses
\end{abstract}

Received December 28, 2009.

Accepted April 21, 2010.

${ }^{1}$ Corresponding author: m.albenzio@unifg.it on the basis of highest content of health-promoting molecules. The metabolic activity of the cheese microflora was also monitored by measuring acetic, lactic, and citric acids during cheese ripening. Cheese acceptability was expressed for color, smell, taste, and texture perceived during cheese consumption. Use of probiotics in trial cheeses did not adversely affect preference or acceptability; in fact, panelists scored probiotic cheeses higher in preference over traditional cheese, albeit not significantly.

Key words: probiotic, rennet paste, ovine cheese, acceptance

\section{INTRODUCTION}

Maturing of cheeses is based on 3 principal biochemical events: glycolysis, proteolysis, and lipolysis. These biochemical pathways, if properly controlled and balanced, lead to desirable and characteristic flavor and texture of cheese.

Biochemical pathways are catalyzed by the metabolic activity of enzymes, originated from milk and coagulant, and from starter and nonstarter lactic acid bacteria. It is reported that environmental factors defined by cheese technology influence the growth and biochemical activities of dairy microorganisms in cheese. Also in ovine cheese, as in most cheese production, selected strains of lactic acid bacteria are added to the milk before renneting to produce lactic acid, thus reducing $\mathrm{pH}$. Main functions of acid production are 1) to promote rennet activity, 2) to aid the expulsion of whey from the curd, thus reducing the moisture content of the cheese, and 3) to help prevent the growth of undesirable bacteria in the cheese (Fox et al., 2000).

Few studies have reported information about effects of coupling starter cultures with probiotic strains on cheese features (Ong et al., 2007; Bergamini et al., 2009); even fewer studies (Corbo et al., 2001) are available for ovine cheese. The addition of probiotic cells during cheesemaking not only contributes to biochemical events of cheese ripening but also imparts functional properties to cheese (Corbo et al., 2001). Santillo and Albenzio (2008) demonstrated that rennet paste containing probiotic bacteria can be used in the production of functional cheese, which maintains the typical features 
of Pecorino cheese. In particular, the incorporation of adequate levels of Lactobacillus acidophilus and a mix of Bifidobacterium longum and Bifidobacterium lactis in rennet paste has been shown to sustain a greater proteolysis and lipolysis in ovine cheeses and lead to improved nutritional features (Santillo et al., 2007a,b, 2009).

In light of this consideration, it is useful to gain information about effects of coupling starter bacteria with probiotics carried into cheese by rennet paste on maturing features of ovine cheese. This study was undertaken to evaluate the effect of rennet containing probiotic strains on the biochemical events of proteolysis, lipolysis, and glycolysis of ovine cheese manufactured with mesophilic and thermophilic starter cultures.

\section{MATERIALS AND METHODS}

\section{Lamb Rennet Paste Characteristics}

Commercial lamb rennet paste was characterized by a clotting activity of 155 international milk-clotting units/g and chymosin-to-pepsin ratio of 70:30. The same batch of lamb rennet paste was divided into 3 aliquots for experimental cheesemaking trials. One aliquot was used as control and named traditional rennet (TR); the second aliquot, named Lb. acidophilus rennet (La-R), was inoculated with $11 \log _{10} \mathrm{cfu} / \mathrm{g}$ of $L b$. acidophilus (LA-5; Chr. Hansen, Milan, Italy); and the third aliquot, named Bifidobacterium rennet (Bb-R), was inoculated with $11 \log _{10} \mathrm{cfu} / \mathrm{g}$ of B. lactis (BB-12) and B. longum (BB-46; Chr. Hansen).

\section{Analyses of Ewe Milk}

Bulk milk and whey samples collected after milk clotting and extraction of the curd were analyzed for fat, protein, and lactose content (MilkoScan, FT 120, Foss Electric, Hillerød, Denmark), pH value (GLP 21 Crison, Barcelona, Spain), and SCC (Fossomatic Minor, Foss Electric).

\section{Pecorino Cheese Production}

Pecorino cheese was produced in an industrial dairy plant (Cooperativa Caseificio Pugliese, Corato, Bari, Italy). Three Pecorino cheesemaking trials were performed in triplicate according to the traditional protocol reported by Santillo et al. (2007a) with modifications: milk was heated $\left(67^{\circ} \mathrm{C}, 20 \mathrm{~s}\right)$ and then cooled to $38^{\circ} \mathrm{C}$ and inoculated using commercial starter cultures Streptococcus thermophilus and Lactobacillus delbrueckii spp. bulgaricus (Danisco France SAS, Sassenage, France), lamb rennet was used as coagulant, and after mold- ing and pressing the curds were held at $42^{\circ} \mathrm{C}$ for $5 \mathrm{~h}$. Cheeses included control cheese made with rennet paste (TR), cheese made with rennet paste containing $L b$. acidophilus culture (LA-5; LA-R), and cheese made with rennet paste containing a mix of $B$. lactis (BB-12) and $B$. longum (BB-46; Bb-R). Cheeses were sampled and analyzed in duplicate at $1,7,15$, and $30 \mathrm{~d}$ of ripening.

\section{Analyses of Cheese}

Chemical Composition and Microbiology of Cheese. Dry matter content and $\mathrm{pH}$ of cheeses were determined according to IDF (1986) and IDF (1989), respectively. Total $\mathrm{N}$ and noncasein $\mathrm{N}$ were determined as described by Gripon et al. (1975), and water-soluble N (WSN) was measured as proposed by Stadhouders (1960).

Mesophilic bacteria $\left(32^{\circ} \mathrm{C}\right.$ for $48 \mathrm{~h}$; plate count agar, Oxoid, Cambridge, UK), total coliforms $\left(37 \pm 0.5^{\circ} \mathrm{C}\right.$ for $24 \mathrm{~h}$; violet red bile agar, I-20100, Biolife, Milano, Italy), and mesophilic lactococci and lactobacilli $\left[37^{\circ} \mathrm{C}\right.$ for 3 d; M17 agar and de Man, Rogosa, and Sharpe (MRS) agar, Merck, Whitehouse Station, NJ] were enumerated. The enumeration of $L b$. acidophilus and a mix of B. longum and B. lactis during cheese ripening was carried out using maltose MRS and cysteine MRS media and the pour-plate technique; the results from plate counts were confirmed by microscopic observation of the isolates from colonies according to Corbo et al. (2001).

Assessment of Proteolysis and Determination of Plasmin and Plasminogen. The $\mathrm{pH}$ 4.6-soluble and insoluble fractions were obtained according to Kuchroo and Fox (1982). The $\mathrm{N}$ fractions were analyzed by urea-PAGE using Protean II xi vertical slab gel equipment (Bio-Rad Laboratories Ltd., Watford, UK) according to the procedure reported in Santillo et al. (2007a). The sum of the bands attributed to $\gamma-\mathrm{CN}$ on the sum of the bands attributed to $\beta$-CN gave the $\gamma / \beta$ ratio.

The peptide profiles of the $\mathrm{pH}$ 4.6-soluble fractions were determined by reverse phase (RP)-HPLC using the operating conditions reported previously (Faccia et al., 2007). Total and individual AA were determined on the WSN fractions by using the EZ:fast physiological AA GC/FID kit (Phenomenex, Torrance, CA) that includes solid-phase extraction cartridge and GC capillary column and a chromatograph HP 5890 under the following working conditions: spilt ratio, $1 / 50$; injector temperature, $250^{\circ} \mathrm{C}$; detector, flame ionization detector at $310^{\circ} \mathrm{C}$; gas, He at constant pressure $(55 \mathrm{kPa})$; initial oven temperature, $110^{\circ} \mathrm{C}$; rate, $14^{\circ} \mathrm{C} / \mathrm{min}$ until $300^{\circ} \mathrm{C}$. The chromatograms were acquired and analyzed by 
Chemstation (Agilent Technologies, Santa Clara, CA) and the peak areas were expressed as arbitrary units per square millimeter. Plasmin (PL)- and plasminogen $(\mathbf{P G})$-derived activities were determined in cheese throughout ripening according to the protocol reported in Santillo and Albenzio (2008).

Assessment of Lipolysis. Volatile FFA in cheese were extracted with diethyl ether:hexane $(1: 1, \mathrm{vol} /$ vol) after grinding with sodium sulfate and addition of $2.5 M$ sulfuric acid (Ha and Lindsay, 1990). Free fatty acids were isolated using an aminopropyl column as adsorbent; the desorption of the FFA was carried out with $2 \%$ formic acid in diethyl ether (de Jong and Badings, 1990). Analysis and identification of FFA were performed according to Santillo et al. (2009).

Total lipids from cheeses were extracted according to de Jong and Badings (1990). Free fatty acid derivatization was performed according to Morrison and Smith (1964). Free fatty acids and conjugated linoleic acid (CLA) were separated on a capillary column (100 m $\times 0.25 \mathrm{~mm}$ i.d, $0.20 \mu \mathrm{m}$ film thickness; HP88, Agilent Technologies). The injector and flame ionization detector temperatures were $260^{\circ} \mathrm{C}$. The programmed temperature was $100^{\circ} \mathrm{C}$ for $1 \mathrm{~min}$, increased to $240^{\circ} \mathrm{C}$ at a rate of $3.5^{\circ} \mathrm{C} / \mathrm{min}$, and maintained at $240^{\circ} \mathrm{C}$ for $15 \mathrm{~min}$. The split ratio was 1:50 and He was carrier gas with a pressure of $227 \mathrm{kPa}$. Pure CLA isomers were purchased as fatty acid methyl esters from Matreya Inc. (Pleasant Gap, PA). All solvents were analytical grade from J. T. Baker (Phillipsburg, NJ).

Determination of Organic Acids and Rheological Parameters in Cheese. Determination of organic acids in cheese was performed on the water-soluble extracts of cheeses prepared according to Kuchroo and Fox (1982) by employing the HPLC method reported by Park and Lee (2006).

Samples for cheese texture analysis were obtained by cutting a slice $(1 \mathrm{~cm}$ thick) from the central diameter of a cheese wheel at $30 \mathrm{~d}$ of ripening. Then, 6 rectangular parallelepipeds $(1 \times 1 \mathrm{~cm}$ thick, $2 \mathrm{~cm}$ long) were obtained from the slide. The cheese samples were left at room temperature for $10 \mathrm{~min}$ before testing. Texture profile analysis was evaluated with an Instron 4301 device (Instron Ltd., High Wycombe, UK) using a modified compression device that avoids transversal elongation of the samples. Each sample underwent 2 cycles of $80 \%$ compression; force by time data were used to calculate the following parameters: hardness, cohesiveness, springiness, gumminess, and chewiness.

Preference and Acceptance Test. A panel of 80 untrained consumers was involved in the analysis. The criterion for recruiting was cheese consumptions and the panel was homogenous regarding gender and age. Each sample was assigned a 3-digit random number, and cheese slices ( $1.5 \mathrm{~mm}$ thick) from the 3 replications of the same batch were mixed randomly so that all replications from the same batch were presented an equal number of times. A glass of water and unsalted crispy bread were provided and consumers were instructed to take a small bite of bread and a sip of water after each cheese tasting. The cheeses were evaluated for color, smell, and taste liking on a 9-point hedonic scale anchored with "like extremely" and "dislike extremely" and with a neutral center point of "neither like nor dislike" (Peryam and Pilgrim, 1957). The consumers were then asked to give their preference among the cheeses.

\section{Statistical Analysis}

All the variables were tested for normal distribution using the Shapiro-Wilk test (Shapiro and Wilk, 1965). Data on chemical composition, PL and PG, and rheological parameters of cheeses were processed by ANOVA using the GLM procedure of SAS (SAS Institute, 1999). The model used was

$$
\mathrm{y}_{\mathrm{ijk}}=\mu+\alpha_{\mathrm{i}}+\beta_{\mathrm{j}}+(\alpha \beta)_{\mathrm{ij}}+\varepsilon_{\mathrm{ijk}}
$$

where $y_{i j k}$ represents the kth measurements of the response variable $y ; \mu$ is the overall mean; $\alpha$ is the effect of the type of rennet used for cheesemaking ( $\mathrm{i}=1-3)$; $\beta$ is the effect of time of ripening of cheese $(j=1-4$ for chemical composition, PL, and PG; $\mathrm{j}=1$ for rheological parameters); $\alpha \beta$ is the interaction of type of rennet $\times$ time of ripening, and $\varepsilon$ is the error. Preference and acceptance data were analyzed using ANOVA with 1 factor (lamb rennet paste).

Results are presented as the least squares means of the rennet paste characteristics for each type of rennet, and the variability of the data are expressed as the standard error of the means of the mean response throughout the whole trial. Significant differences were indicated by $P<0.05$.

Principal component analysis was performed on the correlation matrix using Jump Program (version 3.2.5; SAS Institute, 1999) and was applied to a matrix of 17 analytical cheese parameters (C4:0, C6:0, C8:0, C10:0, C12:0, C14:0, C14:1, C15:0, C16:0, C16:1, C18:0, C18:1, C18:2, C18:3, cis-9,trans-11 CLA, cis-10,trans-12 CLA, trans-9,trans-11 CLA). The 2 most significant principal components (PC) were analyzed using a factorial analysis.

\section{RESULTS AND DISCUSSION}

\section{Milk and Cheese Quality}

In the present study the dairy plant involved in the experimental cheesemaking collected ewe milk over 3 
$\mathrm{d}$ from different farms located in the neighboring area. Owing to the small volume of milk produced by ewes and to the small size of the flocks, the bulk milk is stored for at least $3 \mathrm{~d}$ at refrigeration temperatures in the dairy plant before cheesemaking. Chemical composition, mesophilic cell load, and renneting parameters of ewe bulk milk is presented in Table 1. Good hygienic and nutritional quality were found in ewe bulk milk after $3 \mathrm{~d}$ of storage under refrigeration. This was attributed to both the good quality of raw milk and to the correct storage conditions of the milk, which limited the activities of indigenous and endogenous enzymes associated with somatic cells and microorganisms. It is well known that these enzymes contribute to casein and fat degradation, impairing cheesemaking quality of milk (Albenzio et al., 2009).

Somatic cells and mesophilic cell load are used as indicators of milk hygienic quality, and limits for these parameters are set by the EEC directive 92/46 (European Union, 1992). It has been reported that in ovine milk the bacterial load increases in samples with $>500,000$ somatic cells $/ \mathrm{mL}$ (Sevi et al., 1999). Both hygienic and nutritional features, in particular casein and fat content, led to a good coagulating performance of the milk. Indeed, milk clotting parameters are in the range reported for ewe milk with $<500,000$ somatic cells/mL (Albenzio et al., 2005).

The addition of probiotic cultures to rennet paste was conducted successfully as demonstrated by microbial cell recovery: cell count on specific media was $7 \log _{10}$ $\mathrm{cfu} / \mathrm{g}$ in La-R and Bb-R fresh cheese curd and decreased to $5 \log _{10} \mathrm{cfu} / \mathrm{g}$ at the end of ripening in both cheeses. Mesophilic lactobacilli concentration was $8 \log _{10} \mathrm{cfu} / \mathrm{g}$ in La-R and Bb-R cheese and $6 \log _{10} \mathrm{cfu} / \mathrm{g}$ in TR cheese throughout ripening. Thermophilic lactococci concentration was $4 \log _{10} \mathrm{cfu} / \mathrm{g}$ in all experimental cheeses throughout ripening. Mesophilic lactobacilli included starter cultures, nonstarter lactic acid bacteria, and lactobacilli carried by rennet paste. It is well known that rennet paste obtained by suckling lambs is charac-

Table 1. Somatic cell count, chemical composition, mesophilic cell load, and renneting parameters $( \pm \mathrm{SEM})$ of ewes' bulk milk used for Pecorino cheesemaking $(\mathrm{n}=18)$

\begin{tabular}{lc}
\hline Parameter & Mean \\
\hline SCC, $\log _{10}$ cells $/ \mathrm{mL}$ & $3.50 \times 10^{5} \pm 0.11$ \\
Total mesophilic bacteria, $\log _{10} \mathrm{cfu} / \mathrm{mL}$ & $1.47 \times 10^{5} \pm 0.20$ \\
$\mathrm{pH}$ & $6.59 \pm 0.05$ \\
Fat, \% & $5.92 \pm 0.26$ \\
Protein, \% & $5.60 \pm 0.20$ \\
Lactose, \% & $4.45 \pm 0.03$ \\
Casein, \% & $4.50 \pm 0.12$ \\
Clotting time, min & $15.45 \pm 1.6$ \\
Rate of firming, min & $3.06 \pm 0.50$ \\
Curd firmness, mm & $52.50 \pm 1.80$ \\
\hline
\end{tabular}

terized by an endogenous microflora derived from milk feeding (Santillo et al., 2007a).

Type of rennet affected $\mathrm{pH}$ values $(P<0.05)$, evidencing the lowest value in La-R and Bb-R at $30 \mathrm{~d}$ (Table 2). In this study all experimental cheeses displayed lower $\mathrm{pH}$ values than cheeses obtained with same type of rennet without starter cultures used in cheese production (Santillo and Albenzio, 2008). In the present work the lower $\mathrm{pH}$ values in La- $\mathrm{R}$ and $\mathrm{Bb}-\mathrm{R}$ cheeses than in TR cheese could be ascribed to the metabolism of the added probiotic (i.e., Lb. acidophilus, B. longum, and B. lactis). Thus, both starter cultures and probiotics were able to reduce cheese $\mathrm{pH}$. The optimization of starter concentration should be performed in the dairy plant to control $\mathrm{pH}$ reduction when probiotics and starters are used in combination for cheese production.

Chemical composition at $30 \mathrm{~d}$ of ripening of the experimental cheeses is presented in Table 2. Moisture is regarded as a useful indicator of cheese quality; this parameter was not influenced by the type of rennet used for cheesemaking. Also, protein and fat content at $30 \mathrm{~d}$ of ripening was not different among experimental cheeses. These results were encouraging evidence that the use of experimental rennet pastes led to standardized gross composition of cheeses. On the contrary, differences in intact casein at $30 \mathrm{~d}$, which were highest in cheese obtained using traditional rennet, could be ascribed to differences in the extent of the proteolytic process. The casein content in cheese matrix is widely used to monitor primary proteolysis, being the substrate of the action of the maturing agents. It is well known that rennet plays a major role in casein disruption with liberation of primary proteolytic products, which are in turn the substrate for microbial activities (Pirisi et al., 2007).

\section{Proteolytic Pattern}

Proteolysis is the main process in cheese ripening that determines changes in the texture, attributed to the breakdown of the protein network, and in flavor formation through the release of peptides, free AA, and catabolic products. In particular, primary proteolysis concerns the intact casein chains and is carried out mainly by the coagulant and PL activities. The first period of ripening is essential to the correct development of cheese structure and sensory quality.

Coagulating enzyme in rennet paste acts differently on the principal casein fractions; $\alpha-\mathrm{CN}$, indeed, undergoes higher proteolysis than $\beta$-CN, the former being more susceptible of chymosin activity in cheese. This results in the release of the $\alpha_{S^{-}} \mathrm{I}-\mathrm{CN}$, which is the primary $\alpha_{S^{-}}$ $\mathrm{CN}$ hydrolytic fraction. Figure 1 shows the evolution of $\alpha_{\mathrm{S1}}$-I-CN fraction in the experimental cheeses during 


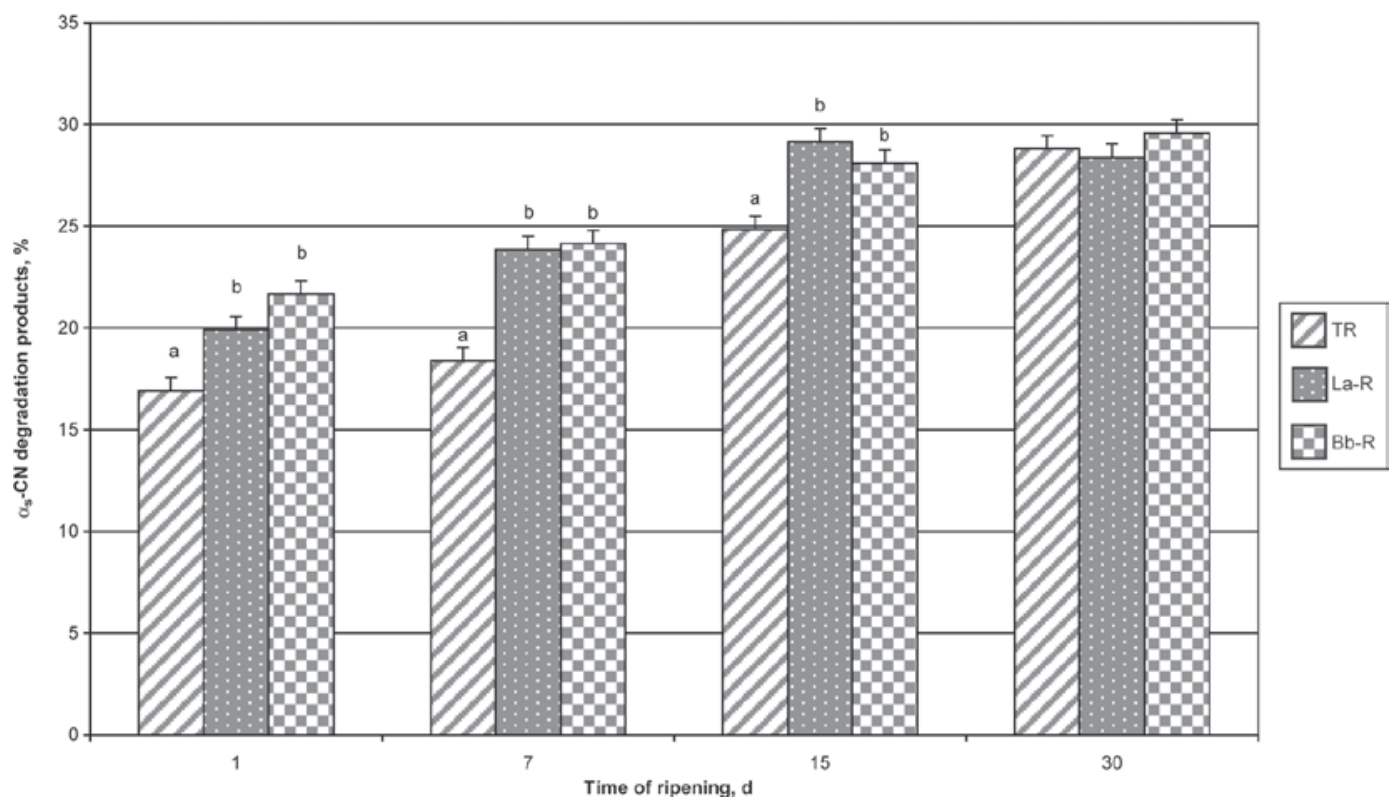

Figure 1. Level of $\alpha_{\mathrm{S}}-\mathrm{I}-\mathrm{CN}$ fraction in cheese manufactured with different rennet paste during ripening. TR $=$ cheese manufactured using traditional lamb rennet paste; La- $\mathrm{R}=$ cheese manufactured using lamb rennet paste containing Lactobacillus acidophilus $(\mathrm{LA}-5) ; \mathrm{Bb}-\mathrm{R}=$ cheese manufactured using lamb rennet paste containing Bifidobacterium lactis (BB-12) and Bifidobacterium longum (BB-46).

ripening. The content of $\alpha_{\mathrm{S} 1}-\mathrm{I}-\mathrm{CN}$ fraction derives from the balance between formation and further hydrolysis. Cheeses produced using rennet paste containing probiotics displayed higher percentages of $\alpha_{\mathrm{S} 1}-\mathrm{I}-\mathrm{CN}$ fraction than traditional cheese up to $15 \mathrm{~d}$ of ripening. This result could be an outcome of the greater hydrolysis of $\alpha-\mathrm{CN}$ fraction because of higher activity of the residual chymosin. It has been reported (Sheehan et al., 2007) that the amount of chymosin retained by cheese and curd increases as $\mathrm{pH}$ of the cheese or curd is decreased before draining. The curd $\mathrm{pH}$ values in the present trial could support this hypothesis, being lowest $(P<0.05)$ in probiotic cheeses $(5.75,5.57$, and $5.54 \pm 0.05$ in $\mathrm{TR}$, La-R, and Bb-R, respectively). The absence of differences at $30 \mathrm{~d}$ in the $\alpha_{\mathrm{S} 1}-\mathrm{I}-\mathrm{CN}$ fraction is in agreement with the lack of differences in $\alpha_{S^{-}}$CN fraction at the same time of ripening (data not shown).

Plasmin is the main proteolytic enzyme involved in $\beta-\mathrm{CN}$ hydrolysis and $\gamma-\mathrm{CN}$ in the cheese matrix; thus, the evolution of $\gamma / \beta$ during cheese ripening has to be considered an index of PL activity. Figure 2 shows the evolution of PL and of $\gamma / \beta$ ratio in experimental cheeses during ripening. Cheeses produced using rennet paste containing probiotics showed higher value of both $\gamma / \beta$

Table 2. Chemical composition and $\mathrm{pH}$ of cheese manufactured using traditional lamb rennet paste and lamb rennet paste containing probiotics at $30 \mathrm{~d}$ of ripening $(\mathrm{n}=18)$

\begin{tabular}{lcccccc}
\hline & \multicolumn{3}{c}{ Lamb rennet paste $^{1}$} & & \\
\cline { 2 - 4 } Parameter & TR & La-R & Bb-R & SEM & $\begin{array}{c}\text { Effect } \\
\text { (rennet) }\end{array}$ \\
\hline pH & $5.11^{\mathrm{b}}$ & $4.91^{\mathrm{a}}$ & $4.96^{\mathrm{a}}$ & 0.05 & $*$ \\
Moisture, \% & 42.81 & 42.58 & 41.74 & 0.06 & $\mathrm{NS}$ \\
Protein, \% & 20.95 & 20.57 & 20.7 & 0.09 & NS \\
Casein, \% & $17.95^{\mathrm{b}}$ & $17.46^{\mathrm{a}}$ & $16.93^{\mathrm{a}}$ & 0.18 & $*$ \\
WSN/TN, $\%$ & 0.27 & 0.26 & 0.26 & 0.01 & NS \\
Total free AA, mg/g of cheese & $127.43^{\mathrm{a}}$ & $387.58^{\mathrm{b}}$ & $313.62^{\mathrm{b}}$ & 27.88 & $* * *$ \\
Fat, \% & 28.61 & 27.78 & 28.17 & 0.71 & NS \\
\hline
\end{tabular}

${ }^{\mathrm{a}, \mathrm{b}}$ Means within a row with different superscripts differ $(P<0.05)$.

${ }^{1} \mathrm{TR}=$ cheese manufactured using traditional lamb rennet paste; La- $\mathrm{R}=$ cheese manufactured using lamb rennet paste containing Lactobacillus acidophilus (LA-5); Bb-R = cheese manufactured using lamb rennet paste containing Bifidobacterium lactis (BB-12) and Bifidobacterium longum (BB-46).

${ }^{2} \mathrm{WSN} / \mathrm{TN}=$ water-soluble $\mathrm{N} /$ total $\mathrm{N}$.

${ }^{*} P<0.05 ;{ }^{* * *} P<0.001$. 


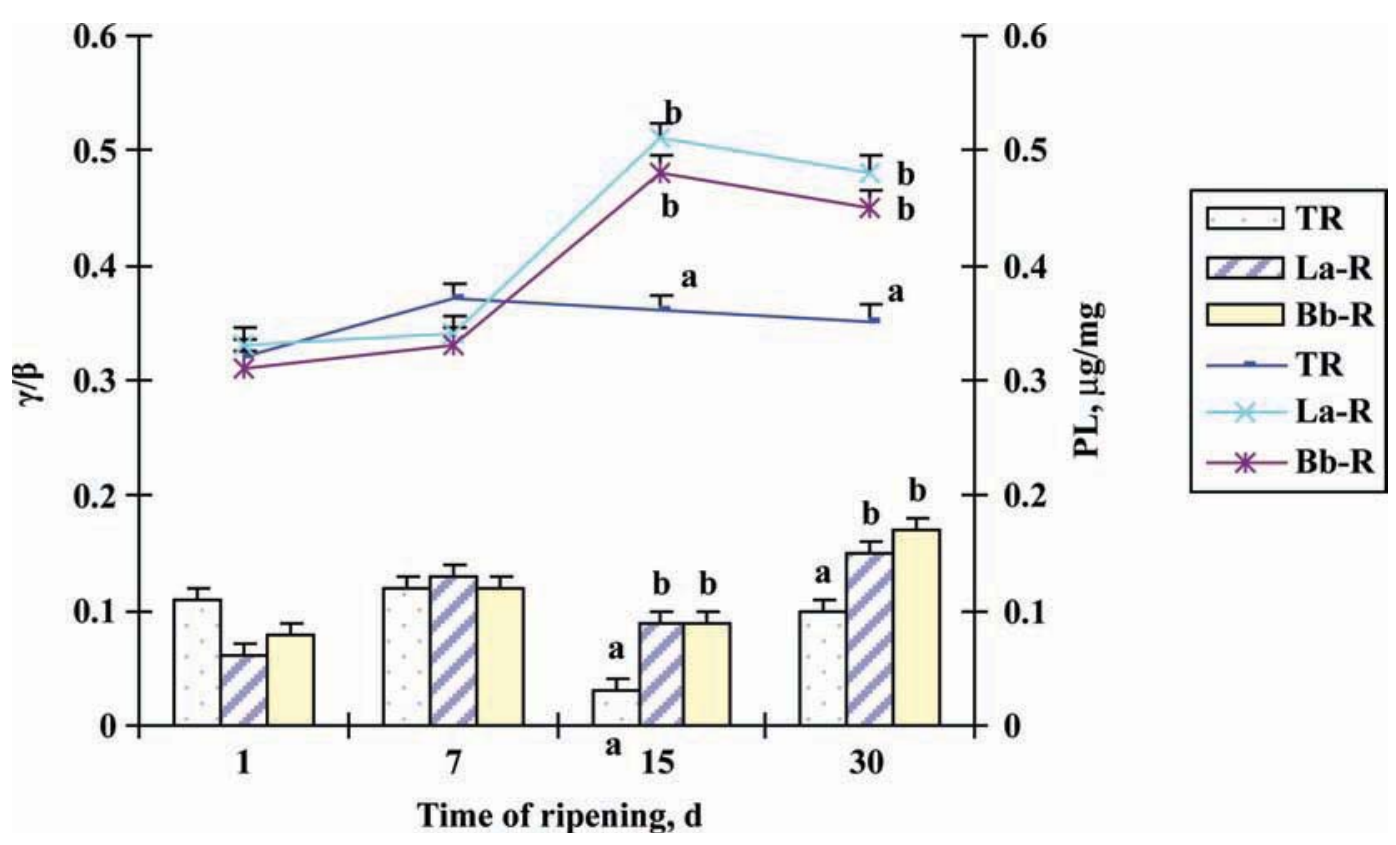

Figure 2. Evolution of plasmin (lines) and of $\gamma / \beta$ ratio (bars) in cheese manufactured with different rennet paste during ripening. TR $=$ cheese manufactured using traditional lamb rennet paste; La- $\mathrm{R}=$ cheese manufactured using lamb rennet paste containing Lactobacillus acidophilus (LA-5); Bb- $\mathrm{R}=$ cheese manufactured using lamb rennet paste containing Bifidobacterium lactis (BB-12) and Bifidobacterium longum (BB-46). Color version available in online PDF.

and PL activity than traditional cheese starting from $15 \mathrm{~d}$. Overall, the extent of proteolysis was different for $\alpha-$ and $\beta-\mathrm{CN}$ fractions, as evidenced by their hydrolysis products at $30 \mathrm{~d}$ of ripening, about $28 \%$ of $\alpha_{\mathrm{S} 1}$-I-CN and $4 \%$ of $\gamma$, respectively. Moreover, the hydrolysis of the principal casein fractions proceeded differently along with the time of ripening. The accumulation of $\alpha-$ and $\beta$-CN hydrolysis products was not synchronized, the former being released mainly within the first 15 $\mathrm{d}$ and the latter starting from $15 \mathrm{~d}$ of ripening as an outcome of the different proteolytic agents acting on intact casein fractions.

Secondary proteolysis was assessed by the analysis of RP-HPLC analysis of water-soluble peptides and of free AA. Although the ripening index (\% WSN/total N) at the end of ripening was not different among cheeses, RP-HPLC profiles (Figure 3) and total free AA (Table 2 ) showed differences in the qualitative features of proteolysis in cheeses. According to studies conducted on Canestrato Pugliese cheese containing bifidobacteria (Corbo et al., 2001), the chromatograms of WSN fraction showed a more complex profile in cheeses made using lamb rennet paste containing probiotics than in traditional cheese. Differences can be observed for the peaks indicated as A through $\mathrm{E}$ in Figure 3, which varied widely among the samples, being higher in cheeses containing probiotics; this was particularly evident for peaks D and E, which were only slightly detected in the control. However, some differences between the 2 probiotic cheese samples were found: the La-R cheese displayed higher areas for peaks D (3,543 arbitrary units $\left./ \mathrm{mm}^{2}\right)$ and $\mathrm{E}\left(2,310\right.$ arbitrary units $\left./ \mathrm{mm}^{2}\right)$ than the $\mathrm{Bb}-\mathrm{R}$ cheese $\left(1,580\right.$ and 952 arbitrary units $/ \mathrm{mm}^{2}$ for peaks $\mathrm{D}$ and $\mathrm{E}$, respectively). The behavior of peptides ascribed to peaks $\mathrm{D}$ and $\mathrm{E}$ has been further investigated by comparing the chromatograms of the probiotic cheeses at different ripening time (data not shown). The evolution of the 2 peaks showed that La-R cheese reached the maximum value for both peaks at 15 $\mathrm{d}$ whereas the highest levels were found in Bb-R cheese at the end of ripening. Further investigation of peaks D and E, which may contain different molecules deriving from protease specificity of probiotics, could be useful for the detection of tracing molecules in cheese associated with the use of lamb rennet paste containing $L b$. acidophilus and a mix of B. longum and B. lactis.

The free AA patterns (data not shown) indicated a significant effect of the use of probiotic strains on both the total amounts and the single peptides. The proteolytic activity of probiotic bacteria gave rise to strong accumulation of free AA: their concentrations in La-R and Bb-R samples were about 2.5 and 3 times higher, respectively, than in the traditional cheese. In general, aspartic acid, glutamic acid, Ala, Tyr, and Phe 


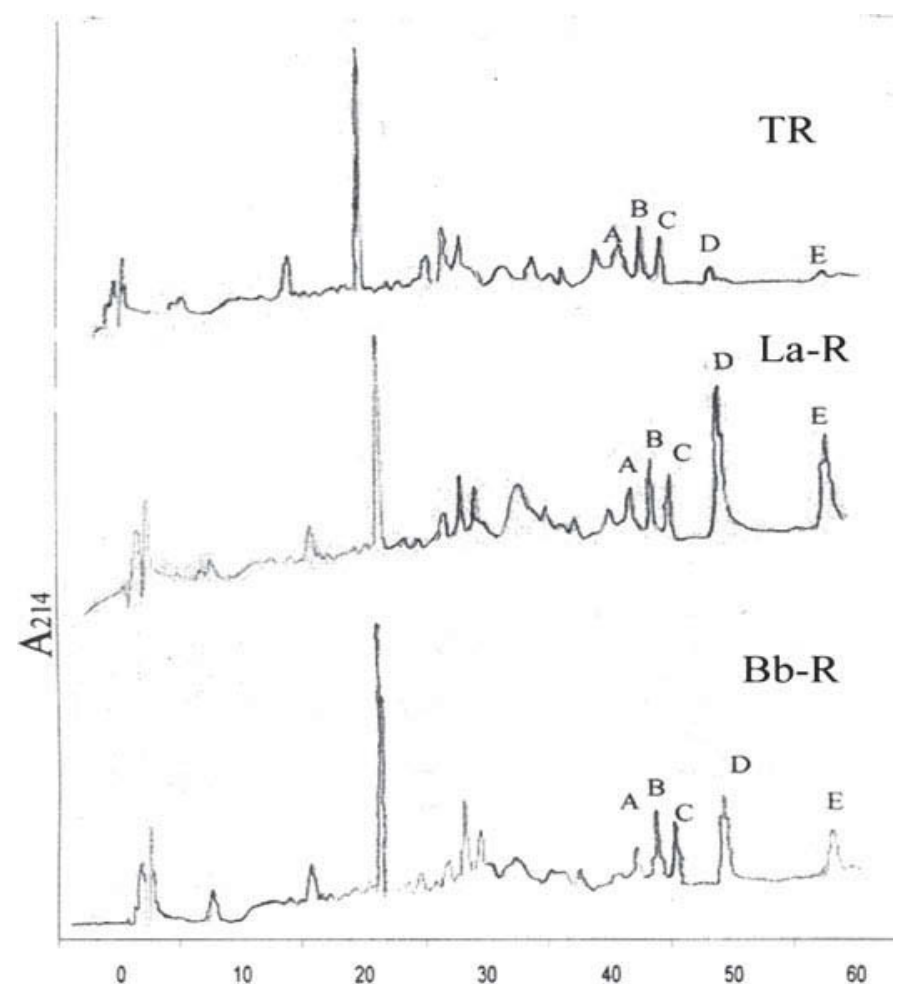

Figure 3. Reverse phase-HPLC profiles of cheese manufactured with different rennet paste at $30 \mathrm{~d}$ of ripening. $\mathrm{TR}=$ cheese manufactured using traditional lamb rennet paste; La- $\mathrm{R}=$ cheese manufactured using lamb rennet paste containing Lactobacillus acidophilus (LA-5); Bb-R = cheese manufactured using lamb rennet paste containing Bifidobacterium lactis (BB-12) and Bifidobacterium longum (BB-46). $\mathrm{A}_{214}=$ absorbance at $214 \mathrm{~nm}$ (arbitrary units); A, B, C, $\mathrm{D}$, and $\mathrm{E}=$ representative peaks of different cheese proteolysis (see Discussion).

were significantly higher in probiotic cheeses than in $\mathrm{TR}$ cheese; in particular, Bb-R cheese displayed the highest levels of Leu, Gly, and Asn.

\section{Lipolytic Pattern}

Fat content was not different among cheeses at the end of ripening and ranged between 28.17 and $28.78 \%$. Total FFA, short-, medium-, and long-chain FFA according to Pirisi et al. (2007), and CLA content of cheese obtained using traditional lamb rennet paste and lamb rennet paste containing probiotics are reported in Table 3. Lipolysis proceeded during ripening with the release of FFA in the cheese matrix in all experimental groups, although at $30 \mathrm{~d}$ TR cheese was characterized by the lowest FFA content. Free fatty acids were higher in probiotic cheeses for short-, medium-, and long-chain molecules than in traditional cheese; in particular, the level of short-chain FFA was the highest in Bb-R cheese whereas the level of long-chain fatty acid was the highest in La-R cheese. It has been proven that probiotic strains are able to liberate fatty acid into the cheese matrix (Collins et al., 2003). As expected, CLA content in La- $\mathrm{R}$ cheese at $30 \mathrm{~d}$ displayed the highest values as an outcome of the ability of Lb. acidophilus to isomerize linoleic acid to CLA. In particular, the highest levels of trans-10, cis-12 CLA were found in La-R cheese. An effect of this isomer on lipid metabolism has been reported; in vitro studies demonstrated a reduction of lipoprotein lipase activity and an increase of glycerol release (Park et al., 1999). The lipolytic profile of ovine cheese produced with traditional rennet paste and rennet paste containing probiotics was studied during ripening; the PC analysis applied to FFA and CLA accounted for approximately $82 \%$ of total variance. The loadings associated with the first 2 factors allowed differentiation among cheeses (Figure 4); the first factor was highly correlated with FFA pattern and is named FFA factor whereas the second factor was highly correlated with CLA content and is named CLA factor. The PC analysis highlighted that cheeses containing $B$. longum and $B$. lactis lay in a zone in which FFA concentration was higher than that of the other cheeses, starting from 15 $\mathrm{d}$ of ripening. Cheeses containing Lb. acidophilus were characterized by the higher loading on the second PC in the PC biplot, owing to the greater weight of CLA in the lipolytic pattern of La-R cheese starting from $15 \mathrm{~d}$ of ripening. High positive loadings on FFA factor were found for Bb-R cheese starting from $15 \mathrm{~d}$ of ripening, whereas La-R cheese was grouped in a zone of the plot characterized by positive loading for CLA.

\section{Glycolysis}

The metabolic activity of the cheese microflora was monitored by measuring acetic, lactic, and citric acids during ripening (Table 4). The amounts of lactic acid detected at the end of ripening of the 3 cheeses were not different (about $12 \mathrm{~g} / \mathrm{kg}$ ). Such concentration is very close to those reported for Brie, Mozzarella, and Brick cheeses (Mullin and Emmons, 1997) and in young probiotic Cheddar cheese (Ong and Shah, 2009). Differences were observed for the evolution of lactic acid during ripening: it increased in all cheeses up to $7 \mathrm{~d}$ as a consequence of the use of residual lactose trapped in the curd; subsequently, TR and La-R cheese showed a decrease whereas $\mathrm{Bb}-\mathrm{R}$ cheese displayed an important increase passing from 7 to 15 . The decrease observed at $30 \mathrm{~d}$ for lactic acid in Bb-R cheese together with the simultaneous increase of acetic acid could be ascribed to the oxidation of lactic acid to acetic acid. Ong et al. (2006) observed that the concentration of acetic acid in probiotic cheese was higher compared with the control because of the addition of bifidobacteria able to produce acetic acid during their metabolism. The final amounts of this acid were higher than those reported 
Table 3. Free fatty acid and conjugated linoleic acid (CLA) contents in ovine cheese manufactured with traditional rennet paste and rennet paste containing probiotics at $30 \mathrm{~d}$ of ripening $(\mathrm{n}=18)$

\begin{tabular}{lccccc}
\hline & \multicolumn{3}{c}{ Lamb rennet paste $^{2}$} & & \\
\cline { 2 - 4 } Parameter $^{1}$ & TR & La-R & Bb-R & SEM & $\begin{array}{c}\text { Effect } \\
\text { (rennet) }\end{array}$ \\
\hline Total FFA, $\mu \mathrm{mol} / \mathrm{g}$ & $10.83^{\mathrm{a}}$ & $13.04^{\mathrm{b}}$ & $13.98^{\mathrm{c}}$ & 0.24 & $* * *$ \\
SCFFA $(4: 0-10: 0), \mu \mathrm{mol} / \mathrm{g}$ & $6.35^{\mathrm{a}}$ & $7.24^{\mathrm{b}}$ & $8.25^{\mathrm{c}}$ & 0.06 & $* * *$ \\
MCFFA $(12: 0-16: 0), \mu \mathrm{mol} / \mathrm{g}$ & $2.33^{\mathrm{a}}$ & $3.06^{\mathrm{b}}$ & $3.14^{\mathrm{b}}$ & 0.04 & $* *$ \\
LCFFA $(18: 0-18: 3), \mu \mathrm{mol} / \mathrm{g}$ & $2.16^{\mathrm{a}}$ & $2.73^{\mathrm{c}}$ & $2.57^{\mathrm{b}}$ & 0.03 & $* * *$ \\
Cis-9, $_{\text {trans-11 CLA, } \mu \mathrm{mol} / \mathrm{g}}$ & $2.52^{\mathrm{a}}$ & $5.04^{\mathrm{b}}$ & $3.97^{\mathrm{b}}$ & 0.42 & $* * *$ \\
Trans-10, cis-12 CLA, $\mu \mathrm{mol} / \mathrm{g}$ & $0.13^{\mathrm{a}}$ & $0.99^{\mathrm{c}}$ & $0.51^{\mathrm{b}}$ & 0.08 & $* * *$ \\
Trans-9, trans-11 CLA, $\mu \mathrm{mol} / \mathrm{g}$ & 0.64 & 1.28 & 0.87 & 0.69 & NS \\
\hline
\end{tabular}

${ }^{\mathrm{a}-\mathrm{C}}$ Means within a row with different superscripts differ $(P<0.05)$.

${ }^{1} \mathrm{SCFFA}=$ short-chain FFA; MCFFA = medium-chain FFA; LCFFA = long-chain FFA

${ }^{2} \mathrm{TR}=$ cheese manufactured using traditional lamb rennet paste; La- $\mathrm{R}=$ cheese manufactured using lamb rennet paste containing Lactobacillus acidophilus (LA-5); Bb-R = cheese manufactured using lamb rennet paste containing Bifidobacterium lactis (BB-12) and Bifidobacterium longum (BB-46).

** $P<0.01 ; * * * P<0.001$.

by Ong and Shah (2009) in pasteurized probiotic Cheddar cheese, and this could be attributed to the use of thermized milk in the present experiment. Citric acid increased in all cheese up to $7 \mathrm{~d}$, and then the trend was different: a continuous decrease was found for the $\mathrm{Bb}-\mathrm{R}$ cheese, whereas a final increase (with concentrations exceeding those found at $1 \mathrm{~d}$ ) was observed for the other 2 samples. However, the level of citric acid assessed at the end of ripening was quite high, and this probably indicates the absence of citrate fermentation.
Citrate, in fact, is involved in the Krebs cycle, where it acts as both substrate and product (Califano and Bevilacqua, 1999).

\section{Cheese Texture and Acceptability}

Cheese texture may be defined as a composite sensory attribute resulting from a combination of physical properties and perceived by the senses of sight, touch, and hearing (Pinho et al., 2004). Mechanical properties

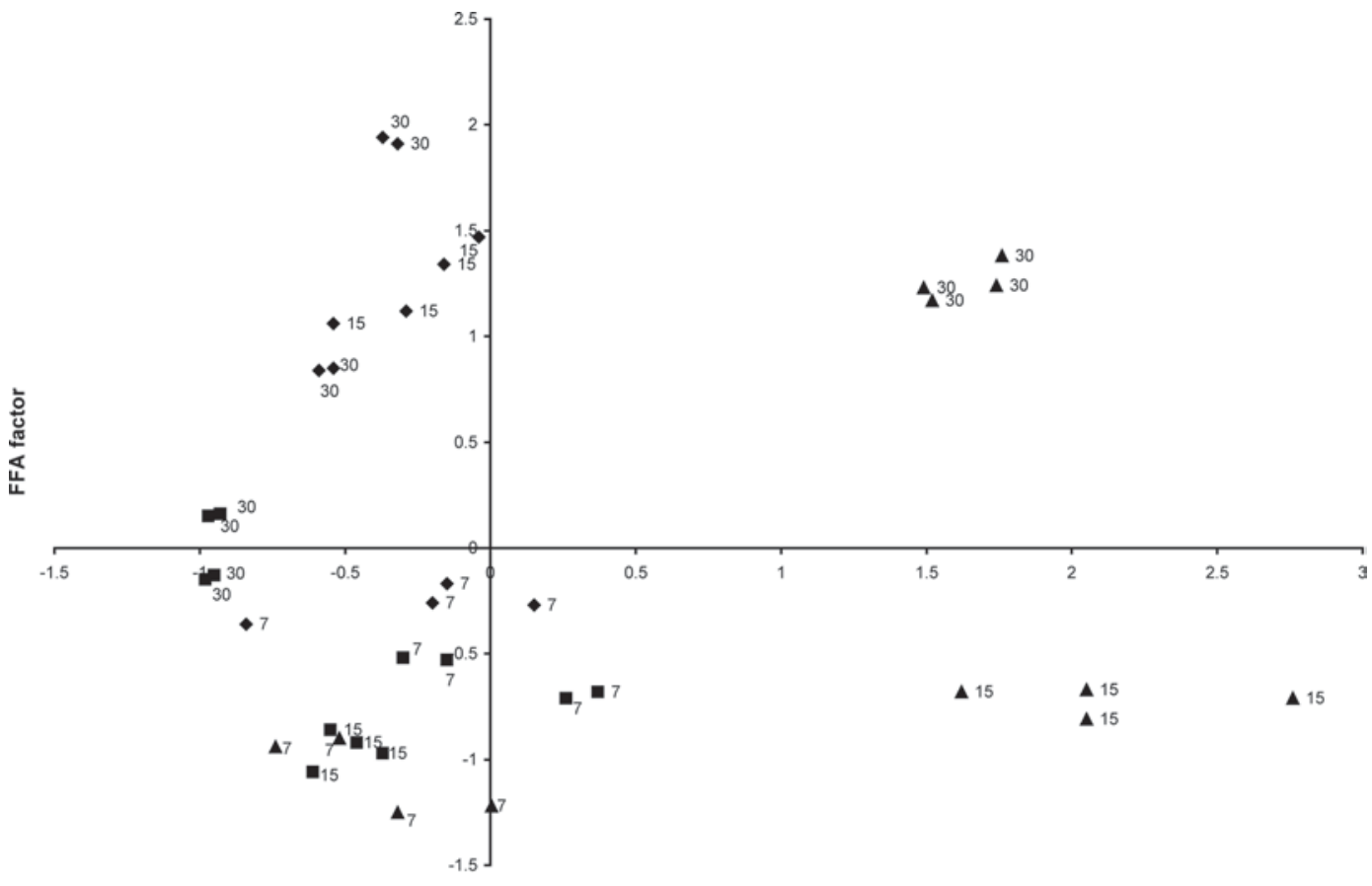

CLA factor

Figure 4. Principal component analysis of FFA and conjugated linoleic acid (CLA) isomers of cheese manufactured with different rennet paste. TR $(\boldsymbol{\square})=$ cheese manufactured using traditional lamb rennet paste; La-R $(\mathbf{\Lambda})=$ cheese manufactured using lamb rennet paste containing Lactobacillus acidophilus (LA-5); Bb-R $(\bullet)=$ cheese manufactured using lamb rennet paste containing Bifidobacterium lactis (BB-12) and Bifidobacterium longum (BB-46). The numbers $(7,15,30)$ by each symbol indicate days of ripening before analysis. 
Table 4. Organic acids contents in ovine cheese manufactured with traditional rennet paste and rennet paste containing probiotics at $30 \mathrm{~d}$ of ripening $(\mathrm{n}=18)$

\begin{tabular}{|c|c|c|c|c|c|c|}
\hline \multirow[b]{2}{*}{ Parameter } & \multirow{2}{*}{$\begin{array}{l}\text { Time of } \\
\text { ripening (d) }\end{array}$} & \multicolumn{3}{|c|}{ Lamb rennet paste ${ }^{1}$} & \multirow[b]{2}{*}{ SEM } & \multirow{2}{*}{$\begin{array}{c}\text { Effect } \\
(\text { rennet } \times \text { time })\end{array}$} \\
\hline & & TR & La-R & $\mathrm{Bb}-\mathrm{R}$ & & \\
\hline \multirow[t]{4}{*}{ Acetic acid, $\mathrm{g} / \mathrm{kg}$ of $\mathrm{DM}$} & 1 & 0.79 & 0.84 & 0.81 & & \\
\hline & 7 & $0.94^{\mathrm{b}}$ & $0.82^{\mathrm{a}}$ & $0.79^{\mathrm{a}}$ & & \\
\hline & 15 & 0.85 & 0.81 & 0.78 & & \\
\hline & 30 & $0.86^{\mathrm{a}}$ & $0.82^{\mathrm{a}}$ & $1.01^{\mathrm{b}}$ & 0.02 & $* * *$ \\
\hline \multirow{4}{*}{ Lactic acid, $\mathrm{g} / \mathrm{kg}$ of $\mathrm{DM}$} & 1 & $11.5^{\mathrm{a}}$ & $12.4^{\mathrm{b}}$ & $11.5^{\mathrm{a}}$ & & \\
\hline & 7 & $13.5^{\mathrm{b}}$ & $13.2^{\mathrm{b}}$ & $12.4^{\mathrm{a}}$ & & \\
\hline & 15 & $11.3^{\mathrm{a}}$ & $12.1^{\mathrm{b}}$ & $14.9^{\mathrm{c}}$ & & \\
\hline & 30 & 12 & 11.9 & 11.9 & 0.02 & $* * *$ \\
\hline \multirow{4}{*}{ Citric acid, $\mathrm{g} / \mathrm{kg}$ of $\mathrm{DM}$} & 1 & $2.99^{\mathrm{a}}$ & $3.13^{\mathrm{b}}$ & $3.18^{\mathrm{b}}$ & & \\
\hline & 7 & $3.78^{\mathrm{b}}$ & $3.43^{\mathrm{a}}$ & $3.42^{\mathrm{a}}$ & & \\
\hline & 15 & 3.07 & 3.14 & 3.09 & & \\
\hline & 30 & $3.33^{\mathrm{b}}$ & $3.35^{\mathrm{b}}$ & $3.01^{\mathrm{a}}$ & 0.05 & $* * *$ \\
\hline
\end{tabular}

${ }^{\mathrm{a}-\mathrm{c}}$ Means within a row with different superscripts differ $(P<0.05)$.

${ }^{1} \mathrm{TR}=$ cheese manufactured using traditional lamb rennet paste; La- $\mathrm{R}=$ cheese manufactured using lamb rennet paste containing Lactobacillus acidophilus (LA-5); Bb-R = cheese manufactured using lamb rennet paste containing Bifidobacterium lactis (BB-12) and Bifidobacterium longum (BB-46).

$* * * P<0.001$.

of cheese are related to the composition, structure, and strength of the attractions between the structural elements in cheese. The behavior of experimental cheese subjected to fixed stress was described by hardness, firmness, springiness, adhesiveness, cohesiveness, gumminess, and chewiness. Although cheeses were ripened for a short time, textural evaluation highlighted significant differences in the cheese hardness, being lower $(P$ $<0.001)$ in La-R and Bb-R cheeses than in TR (15.65, 15.44 , and $22.38 \pm 1.10 \mathrm{~N}$, respectively). Chemical and proteolytic features of cheeses may explain this result; lower $\mathrm{pH}$ in probiotic cheeses, indeed, facilitated a major casein dissociation. Casein disaggregation exposes a larger surface area of proteins to proteinases and leads to an increase in enzyme-substrate interaction (Upreti et al., 2006). Chymosin, the primary proteolytic agent, is involved in cheese ripening and has been associated with softening of cheese texture via hydrolysis of $\alpha_{\mathrm{S1}^{-}}$ I-CN, which was accumulated at the highest levels in probiotic cheeses.

Although textural evaluation by instrumental methods is standardized and more reproducible, it is necessary to evaluate the consumer acceptance of cheese. Lactobacillus acidophilus, B. longum, and B. lactis used for ovine cheese production have been shown to be not associated with impaired sensory attributes (Santillo and Albenzio, 2008). In the present work, sensory analysis aimed to study consumer acceptance of cheeses obtained using commercial starters in the milk acidification phase and probiotic rennet paste in the coagulation phase. Addition of lactobacilli in cheese has been associated with an increased proteolysis and intensification of flavor; proteolytic enzymes produced by certain probiotic adjunct were reported to be able to degrade bitter peptides (Lynch et al., 1999; Ong et al., 2007). Cheese acceptability was expressed for color, smell, taste, and texture perceived during cheese consumption; all these attributes scored values over 7 and no differences were reported among cheeses. This result was confirmed by cheese preference test that displayed comparable values among cheeses $(7.88,8.18$, and 8.11 \pm 0.10 in TR, La-R, and Bb-R, respectively) even if probiotic cheeses scored slightly higher values than traditional cheese.

\section{CONCLUSIONS}

Starter cultures coupled with probiotics strains contained in rennet paste affected the acidification and coagulation phases leading to the lowest $\mathrm{pH}$ in curd and cheese containing probiotics during ripening. As a consequence, maturing profile was different among cheeses. Primary proteolysis evidences a major breakdown of both $\alpha$ - and $\beta-C N$ fractions in cheese containing $L b$. acidophilus and a mix of $B$. longum and B. lactis; this was probably the main factor affecting cheese hardness, which was the lowest in the same cheeses. Furthermore, qualitative evaluation of WSN fraction by RP-HPLC evidences specific peaks only in cheese containing probiotic in the highly probiotic zone because of enzymatic activity of probiotic cells. More intense lipolysis was detected in cheese containing probiotics in terms of both FFA and CLA content; the latter was found at the highest levels in cheese containing $L b$. acidophilus. Use of probiotics in trial cheeses did not adversely affect preference or acceptability; in fact, panelists scored probiotic cheeses higher in preference over traditional cheese, albeit not significantly. 


\section{ACKNOWLEDGMENTS}

The authors thank Donatella E. Russo and Daniela Ruggieri (Department PrIME, University of Foggia, Italy) for expert technical assistance.

\section{REFERENCES}

Albenzio, M., M. Caroprese, A. Santillo, R. Marino, A. Muscio, and A. Sevi. 2005. Proteolytic patterns and plasmin activity in ewe milk as affected by somatic cell count and stage of lactation. J. Dairy Res. 72:86-92.

Albenzio, M., A. Santillo, M. Caroprese, F. d'Angelo, R. Marino, and A. Sevi. 2009. Role of endogenous enzymes in proteolysis of sheep milk. J. Dairy Sci. 92:79-86.

Bergamini, C. V., E. R. Hynes, S. B. Palma, N. G. Sabbag, and C A. Zalazar. 2009. Proteolytic activity of three probiotic strains in semi-hard cheese as single and mixed cultures: Lactobacillus acidophilus, Lactobacillus paracasei and Bifidobacterium lactis. Int. Dairy J. 19:467-475.

Califano, A. N., and A. E. Bevilacqua. 1999. Freezing low moisture Mozzarella cheese: Changes in organic acid content. Food Chem. 64:193-198.

Collins, Y. F., P. L. H. MacSweeney, and M. G. Wilkinson. 2003. Lipolysis and free fatty acid catabolism in cheese: A review of current knowledge. Int. Dairy J. 13:841-866.

Corbo, M. R., M. Albenzio, M. De Angelis, A. Sevi, and M. Gobbetti. 2001. Microbiological and biochemical properties of Pecorino hard cheese supplemented with bifidobacteria. J. Dairy Sci. 84:551561

de Jong, C., and H. T. Badings. 1990. Determination of free fatty acids in milk and cheese. Procedures of extraction, clean up, and capillary gas chromatographic analysis. J. High Res. Chromat. 13:94-98

European Union, 1992. EEC 92/46. Council directive 92/46/EEC of 16 June 1992 laying down the health rules for the production and placing on the market of raw milk, heat-treated milk and milkbased products. Off. J. L 268:1.

Faccia, M., G. Gambacorta, F. Caponio, S. Pati, and A. Di Luccia. 2007. Influence of type of milk and ripening time on proteolysis and lipolysis in a cheese made from overheated milk. Int. J. Food Sci. Technol. 42:427-433.

Fox, P. F., T. P. Guinee, T. M. Cogan, and P. L. H. McSweeney. 2000. Fundamentals of Cheese Science. Aspen Publishers Inc., Gaithersburg, MD.

Gripon, J. C., M. J. Desmazeaud, D. Le Bars, and J. L. Bergere. 1975. Etude du role des micro-organismens et des enzymes au cours de la maturation des fromages. Lait 548:502-515.

Ha, K. J., and R. C. Lindsay. 1990. Method for the quantitative analysis of volatile free and total branched-chain fatty acids in cheese and milk fat. J. Dairy Sci. 73:1988-1999.

IDF (International Dairy Federation). 1986. Cheese and processed cheese products. Determination of dry matter. IDF Standard No 4. FIL-IDF, Brussels, Belgium.

IDF (International Dairy Federation). 1989. Determination of $\mathrm{pH}$. Standard No 115A. FIL-IDF, Brussels, Belgium.

Kuchroo, C. N., and P. F. Fox. 1982. Soluble nitrogen in Cheddar cheese: Comparison of extraction procedures. Milchwissenschaft 37:331-335.

Lynch, C. M., D. D. Muir, J. M. Banks, P. L. H. McSweeney, and F. F. Fox. 1999. Influence of adjunct cultures Lactobacillus paracasei ssp. paracasei or Lactobacillus plantarum on Cheddar cheese ripening. J. Dairy Sci. 82:1618-1628.

Morrison, W. R., and L. M. Smith. 1964. Preparation of fatty acids methyl esters and dimethylacetals from lipids with boron fluoride methanol. J. Lipid Res. 5:600-608.
Mullin, W. J., and D. B. Emmons. 1997. Determination of organic acids and sugars in cheese, milk and whey by high performance liquid chromatography. Food Res. Int. 30:147-151.

Ong, L., A. Henriksson, and N. P. Shah. 2006. Development of probiotic Cheddar cheese containing Lb. acidophilus, Lb. paracasei, Lb. casei and Bifidobacterium spp. and the influence of these bacteria on proteolytic patterns and production of organic acid. Int. Dairy J. $16: 446-456$.

Ong, L., A. Henriksson, and N. P. Shah. 2007. Chemical analysis and sensory evaluation of Cheddar cheese produced with Lactobacillus acidophilus, Lb. casei, Lb. paracasei or Bifidobacterium sp. Int. Dairy J. 17:937-945.

Ong, L., and N. P. Shah. 2009. Probiotic Cheddar cheese: Influence of ripening temperatures on survival of probiotic microorganisms, cheese composition and organic acid profiles. LWT-Food Sci. Technol. 42:1260-1268.

Park, Y. W., and J. H. Lee. 2006. Effect of freezing on organic acid contents and lipolytic index of plain soft and Monterey Jack goat milk cheeses. Small Rumin. Res. 63:58-65.

Park, Y.. J. M. Storkson, K. J. Albright, W. Liu, and M. W. Pariza. 1999. Evidence that the trans-10, cis12 isomer of conjugated linoleic acid induces body composition changes in mice. Lipids $34: 235-241$

Peryam, D. R., and F. J. Pilgrim. 1957. Hedonic scale method of measuring food preferences. Food Technol. 11:9-14.

Pinho, O., E. Mendes, M. M. Alves, and I. M. Ferreira. 2004. Chemical, physical, and sensorial characteristics of "Terrincho" ewe cheese: Changes during ripening and intravarietal comparison. J. Dairy Sci. 87:249-257.

Pirisi, A., G. Pinna, M. Addis, G. Piredda, R. Mauriello, S. De Pascale, S. Caira, G. Mamone, P. Ferranti, F. Addeo, and L. Chianese. 2007. Relationship between the enzymatic composition of lamb rennet paste and proteolytic, lipolytic pattern and texture of PDO Fiore Sardo ovine cheese. Int. Dairy J. 17:143-156.

Santillo, A., and M. Albenzio. 2008. Influence of lamb rennet paste containing probiotic on proteolysis and rheological properties of Pecorino cheese. J. Dairy Sci. 91:1733-1742.

Santillo, A., M. Albenzio, M. Quinto, M. Caroprese, R. Marino, and A. Sevi. 2009. Probiotic in lamb rennet paste enhances rennet lipolytic activity, and CLA and linoleic acid content in Pecorino cheese. J. Dairy Sci. 92:1330-1337.

Santillo, A., M. Caroprese, R. Marino, A. Muscio, A. Sevi, and M. Albenzio. 2007a. Influence of lamb rennet paste on chemical and enzymatic characteristics of Pecorino Foggiano cheese. Int. Dairy J. $17: 535-546$.

Santillo, A., M. Quinto, M. Dentico, A. Muscio, A. Sevi, and M. Albenzio. 2007b. Rennet paste from lambs fed a milk substitute supplemented with Lactobacillus acidophilus: Effects on lipolysis in ovine cheese. J. Dairy Sci. 90:3134-3142.

SAS Institute. 1999 SAS/STAT User's Guide. Version 8.1. SAS Institute, Cary, NC.

Sevi, A., M. Albenzio, L. Taibi, D. Dantone, S. Massa, and G. Annicchiarico. 1999. Changes of somatic cell count through lactation and their effects on nutritional, renneting and bacteriological characteristics of ewe's milk. Adv. Food Sci. 21:122-127.

Shapiro, S. S., and M. Wilk. 1965. An analysis of variance test for normality. Biometrika 52:591-601.

Sheehan, J. J., M. A. Fenelon, M. G. Wilkinson, and P. L. H. McSweeney. 2007. Effect of cook temperature on starter and non-starter lactic acid bacteria viability, cheese composition and ripening indices of a semi-hard cheese manufactured using thermophilic cultures. Int. Dairy J. 17:704-716.

Stadhouders, J. 1960. The hydrolysis of protein during ripening of Dutch cheese. The enzymes of the bacteria involved. Nether. Milk Dairy J. 14:106-110.

Upreti, P., L. E. Metzger, and K. D. Hayes. 2006. Influence of calcium and phosphorus, lactose, and salt-to-moisture ratio on Cheddar cheese quality: Proteolysis during ripening. J. Dairy Sci. 89:444453. 